\title{
SUPPRESSION EFFECT OF MAHKOTA DEWA (PHALERIA MACROCARPA) LEAF EXTRACT IN CHITOSAN NANOPARTICLES ON THE SMALL INTESTINE OF DEXTRAN SULFATE SODIUM-INDUCED MICE: FOCUS ON MITOSIS AND HYPERPLASIA
}

\author{
KUSMARDI KUSMARDI ${ }^{1}$, ARIF RAMADHAN TAMZIR ${ }^{2}$, SANTI WIDIASARI ${ }^{3}$, ARI ESTUNINGTYAS ${ }^{4 *}$
}

\begin{abstract}
${ }^{1}$ Department of Anatomic Pathology, Faculty of Medicine, Universitas Indonesia, Jakarta, Indonesia. ${ }^{2}$ Department ofPharmacology, Faculty of Medicine, Universitas Indonesia, Jakarta, Indonesia. ${ }^{3}$ Department of Pharmacology, Biomedical Science Magister Program, Faculty of Medicine, Universitas Indonesia, Jakarta, Indonesia. ${ }^{4}$ Department of Pharmacology, Faculty of Medicine, Universitas Indonesia, Jakarta, Indonesia. Email: ari_handoyo@yahoo.com
\end{abstract}

Received: 07 December 2017, Revised and Accepted: 17 February 2018

\section{ABSTRACT}

Objective: The incidence of small intestine cancer (SIC) is rising despite available preventive measures. Kaempferol and quercetin are a potential chemopreventive agent for SIC, but in vivo findings are inconclusive. We aim to study the effects of kaempferol and quercetin on colitis-associated small intestine carcinogenesis in mice.

Methods: Suppression effect was tested using mice divided into 6 groups of treatment, i.e.; normal (N) group, negative control (NC), leaf extract (medium dose [MD]) dose 12.5 and $25 \mathrm{mg} / \mathrm{kg}$ body weight (BW), leaf extract chitosan and nanoparticle of mahkota dewa (NPMD) dose 6.25 and $12.5 \mathrm{mg} / \mathrm{kg}$ BW. Dextran sulfate sodium induction of $1 \% \mathrm{w} / \mathrm{v}$ was administered through drinking water for 6 weeks of treatment. The suppression effect was observed histopathologically by counting the mitotic cells and hyperplasia cells of the crypt of small intestine with hematoxylin-eosin staining.

Results: Mitosis cells mean of NC group was not significant difference either with MD 12.5 ( $p=0.394)$ or MD $6.5(p=0.310)$. However, mitosis cell mean appears to be lower in the NPMD $12.5(\mathrm{p}=0.09)$ and NPMD $6.25(\mathrm{p}=0.05)$ groups than the NC group. There was a significant difference among the mean of hyperplasia NC group and MD and also NPMD group. Significant difference also can be showed between MD 12.5 and MD 25 ( $p=0.026$ ), and between NPMD 6.25 and NPMD 12.5 ( $\mathrm{p}=0.002)$, and between MD 12.5 and NPMD 12.5 ( $\mathrm{p}=0.002)$.

Conclusion: Our results demonstrate suppression of hyperplasia small intestine by either nanoparticle or extract of Phaleria macrocarpa extracts. The suppression of mitosis was showed by administration of nanoparticle.

Keywords: Small intestine, Chemoprevention, Phaleria macrocarpa, Kaempferol, Quercetin, Mitosis, Hyperplasia.

(C) 2018 The Authors. Published by Innovare Academic Sciences Pvt Ltd. This is an open access article under the CC BY license (http://creativecommons. org/licenses/by/4. 0/) DOI: http://dx.doi.org/10.22159/ajpcr.2018.v11i6.24159

\section{INTRODUCTION}

Small intestine cancer (SIC) is the third most common cancer in men and second most common cancer in women, representing $10 \%$ and $9.1 \%$ of all cases, respectively. SIC accounts for 1.4 million new cancer cases in 2012, a majority of which (almost 55\% cases) are diagnosed in the developed world [1,2]. SIC is preventable through routine screening for precancerous tumors with available methods. Nevertheless, the incidence of SIC is rising in most developing countries and some developed countries. This rise is thought to reflect an increase in the prevalence of SIC risk factors, which are largely related to dietary and lifestyle choices, including high intakes of red meat and processed foods, low fiber intake, low physical activity, obesity, smoking, and alcohol use $[2,3]$. For this reason, exploration of new preventive strategies, particularly chemoprevention, is gaining interest.

Phaleria macrocarpa belongs to the Moraceae family and widely grown in the islands of Java, Sumatra, Kalimantan, and Maluku. PM is also found in Malaysia and Thailand, and grow in a small extent in China. In Indonesia, PM is known as Mahkota Dewa for many are found grown well along in the South of Kalimantan. In its natural habitat, PM is an epiphytic grows on another plant or stick to either larger plants or on the rocks on which it depends for mechanical support but not for nutrients [4-6].

Numerous epidemiological studies have found an association between P. macrocarpa intake and better health outcomes, particularly a reduced risk of developing various cancers, including breast, lung, prostate, bladder, and endometrial cancer [7]. Recently, a systematic review and meta-analysis of 17 epidemiological studies have shown that $P$. macrocarpa intake has a protective effect against SIC, particularly in Asian populations. This makes P. macrocarpa an attractive candidate to explore for novel cancer-preventive agents [8].

One of the agents that had been identified in $P$. macrocarpa is kaempferol and quercetin, the 43 residues-long, $5.5 \mathrm{kDa}$ subunit of the cotyledon-specific Gm2S-1 protein (2S albumin) that is also found in barley. Transient expression of kaempferol and quercetin leads to mitotic arrest and cell death in murine embryo fibroblasts, murine hepatoma cells, and human breast cancer cells. Suggests that kaempferol and quercetin have the potential to suppress both virally induced and chemically induced carcinogenesis. Kaempferol and quercetin promote apoptosis in fibroblasts expressing the viral oncogene E1A [9], suppresses small intestine formation in fibroblasts expressing the viral oncogene ras, and inhibits 7,12-dimethylbenz[a] anthracene-induced skin papilloma development in mice. In addition to its antitumorigenic activity, kaempferol and quercetin also exhibit antioxidant, anti-inflammatory, and cholesterol-regulating properties [10-13]

In vitro studies have demonstrated the suppressive effects exerted by kaempferol and quercetin on small intestine carcinogenesis. Kaempferol and quercetin were found to block cell cycle at the G2 phase and 
induce apoptosis in KM12L4 and HT-29 SIC cells and were otherwise cytotoxic to HCT-116 and RKO SIC cells. The antiproliferative and proapoptotic effects of kaempferol and quercetin were shown to be dosedependent [14]. In vivo data have supported these findings, but are still inconclusive. Kaempferol and quercetin administered intraperitoneally were found to have inhibitory effects on SIC liver metastasis and to potentiate those of oxaliplatin. Inhibition of SIC liver metastasis by intraperitoneally administered kaempferol and quercetin has been replicated by another study. That study failed to demonstrate the inhibition of SIC liver metastasis with orally administered kaempferol and quercetin $[8,9]$. To date, only one study used colitis-associated SIC model. Mice given isoflavone-free $P$. macrocarpa protein concentrate as the sole source of protein have less severe crypt epithelial cell hyperplasia and dysplasia on induction of small intestine inflammation. The effect of administering varying doses of kaempferol and quercetin on colitis-associated small intestine carcinogenesis has not been explored. Here, we demonstrated inhibition of colitis-associated small intestine carcinogenesis in mice treated with kaempferol and quercetin in the form of P. macrocarpa extract [15].

\section{METHODS}

\section{Animal}

Male 12-week-old Swiss Webster mice with an average weight of $25 \mathrm{~g}$ were supplied by the Health Research and Development Agency of the Ministry of Health of the Republic of Indonesia. The mice were kept in independent ventilation cages $(48 \mathrm{~cm} \times 35 \mathrm{~cm} \times 20 \mathrm{~cm})$ with free access to food and water under controlled humidity ( $55 \pm 5 \%$ ), light/dark cycle $(12 \mathrm{~h} / 12 \mathrm{~h})$, and temperature $\left(23^{\circ} \mathrm{C} \pm 1^{\circ} \mathrm{C}\right)$. The mice were carefully examined to ensure that they are in healthy conditions and acclimatized for 1 week before any experimental procedure was performed. All protocols and surgical procedures were approved by the Animal Care and Use Committee of the Faculty of Medicine of the University of Indonesia.

\section{Induction of small intestine with dextran sulfate sodium (DSS) and} treatment of extract

Mice were randomized into the following 6 groups: Normal mice $(\mathrm{N})$ group, which received no other treatment; negative control (NC) group, which received DSS 2\% w/v (administered with drinking water starting at week 1 treatment then followed by administration of drinking water without DSS [16-21] for the next 1 week and repeated up to 3 DSS cycles); treatment groups medium dose (MD) 25 which received DSS $2 \% \mathrm{w} / \mathrm{v}+$ Mahkota Dewa leaf extract $25 \mathrm{mg} / \mathrm{kg}$ body weight (BW) and MD 12.5 which received DSS $2 \% \mathrm{w} / \mathrm{v}+$ Mahkota Dewa leaf extract 25 $\mathrm{mg} / \mathrm{kg}$ BW; nanoparticle of mahkota dewa (NPMD) 12.5 and 6.25 which received DSS $2 \% \mathrm{~b} / \mathrm{v}+$ Dewa Mahkota leaf extract in nano chitosan particle 12.5 and $6.25 \mathrm{mg} / \mathrm{kg} \mathrm{BW}$. All extracts were given orally starting at week 3 for 5 weeks. At the end of treatment, the mice were euthanized with ketamine for small intestine tissue collection and embedding into paraffin blocks [22,23].

\section{Hematoxylin-eosin (HE) staining}

Paraffin-embedded tissue samples are sliced into $4 \mu \mathrm{m}$-thick sections, which were then placed on an object glass for HE staining. The sections were deparaffinized with Xylol I, II, and III for 5 min each, then rehydrated with absolute alcohol, $96 \%$ alcohol, and $70 \%$ alcohol for $5 \mathrm{~min}$ each before being washed in running water for $5 \mathrm{~min}$. After that, the slides were placed in hematoxylin for $7 \mathrm{~min}$, washed in running water for $10 \mathrm{~min}$, placed in a saturated lithium carbonate solution for 1-2 min, and washed again in running water for $5 \mathrm{~min}$. Slides with insufficient bluing were transferred back into hematoxylin for another 2 min then washed in running water. The slides were then placed in eosin for 1-2 min. After being stained, the slides were dehydrated with $70 \%$ alcohol, $80 \%$ alcohol, $96 \%$ alcohol, and absolute alcohol for $3 \mathrm{~min}$ each, then cleared with Xylol I, II, and III before being mounted with Entellan. Blinded histological examination was performed to evaluate crypt epithelial cell mitosis and hyperplasia.

\section{Statistical analysis}

All data are presented and were analyzed using Mann-Whitney U-test with SPSS 20.0 statistical package. $\mathrm{p}<0.05$ was considered statistically significant.

\section{RESULTS}

\section{Effect of $P$. macrocarpa extract administration on mitosis}

The effect of $P$. macrocarpa extract administration on crypt epithelial cell mitosis after induction of DSS is shown in Fig. 1. Mann-Whitney U-test showed that mitosis cells mean of NC group was not significant difference either with MD $12.5(\mathrm{p}=0.394)$ or MD $6.5(\mathrm{p}=0.310)$. However, mitosis cell mean appears to be lower in the NPMD $12.5(\mathrm{p}=0.09)$ and NPMD $6.25(\mathrm{p}=0.05)$ groups than the NC group. The NPMD 12.5 has the lower mitosis cell mean than MD 12.5 group ( $\mathrm{p}=0.026)$.

Effect of $P$. macrocarpa extract administration on the hyperplasia The effect of $P$. macrocarpa extract administration on the mean of crypt epithelial cell hyperplasia after induction of DSS is shown in Fig. 2. The mean of hyperplasia cells is also shown to be lower in treatment groups than the NC group. There was significant difference among mean of hyperplasia NC group and MD and also NPMD group. Significant difference also can be showed between MD 12.5 and MD 25 ( $\mathrm{p}=0.026)$, and between NPMD 6.25 and NPMD 12.5 ( $\mathrm{p}=0.002)$, and between MD 12.5 and NPMD 12.5 ( $\mathrm{p}=0.002)$.

\section{DISCUSSION}

This study uses the colitis-associated SIC mice model. DSS induces chronic inflammation, involving such molecular processes as

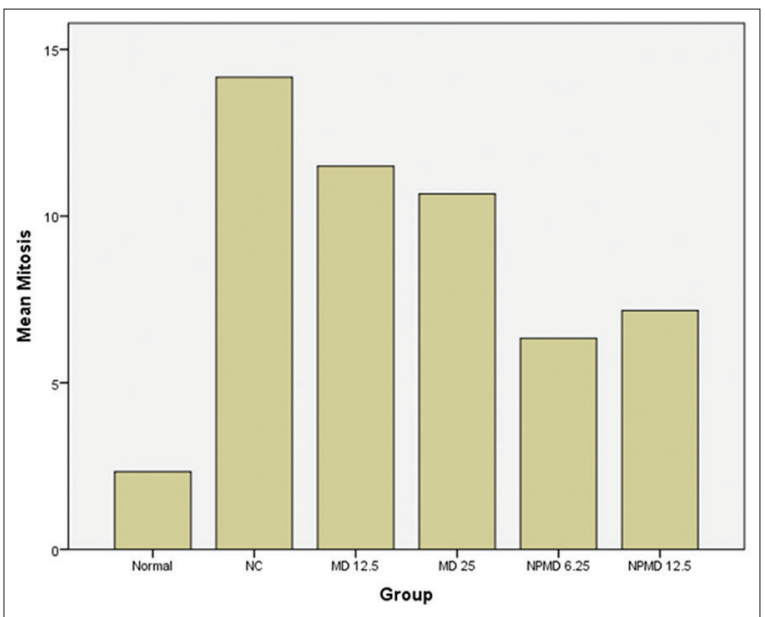

Fig. 1: Mean mitosis cells of mice crypt epithelial cells after induction of dextran sulfate sodium

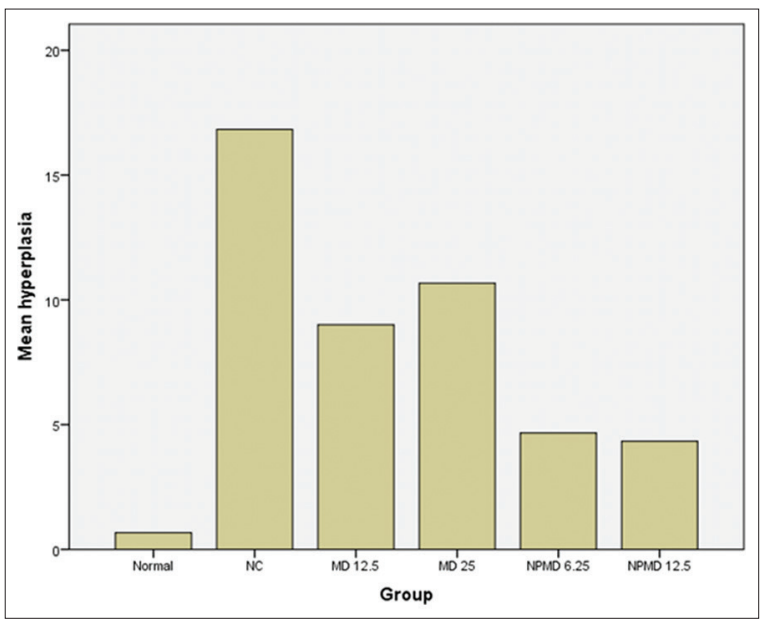

Fig. 2: Mean hyperplasia score of mice crypt epithelial cells after induction of dextran sulfate sodium 
overproduction of reactive oxygen and nitrogen species, upregulation of cytokines and enzymes of arachidonic acid biosynthetic pathway, and dysfunction of the intestinal immune system. Any or all of these events may contribute to small intestine inflammation [24], which is observed as increased mitosis and hyperplasia of crypt epithelial cells.

Our results support the hypothesis that $P$. macrocarpa provides protection against colitis-associated SIC in male Swiss Webster mice. Daily administration of P. macrocarpa extract at a dose of 12.5 or $25 \mathrm{mg} / \mathrm{kg}$ BW after small intestine induction with DSS did not suppress mitosis, but it showed suppress hyperplasia of crypt epithelial cells. It was not similar to the administration of (NPMD). DSS-induced crypt epithelial cell hyperplasia and mitosis were suppressed by daily administration of NPMD. This can potentially be explained by the higher doses of kaempferol and quercetin in those groups with greater reduction in hyperplasia. It is unclear why suppression of mitosis does not follow this trend. As hyperplasia is the combined effect of increased mitosis and decreased apoptosis, it is possible that the reduction in hyperplasia observed is contributed primarily by an increase in crypt epithelial cell apoptosis and that suppression of mitosis is simply less pronounced.

P. macrocarpa has long been suspected to lower cancer risk, and many substances with potential antitumorigenic properties have been identified in P. macrocarpa [25].

Kaempferol and quercetin have been identified recently as a novel chemopreventive agent in P. macrocarpa.

To the best of our knowledge, ours is the first study to demonstrate suppression of mitosis and hyperplasia in colitis-associated SIC mice model by kaempferol and quercetin in P. macrocarpa extract. However, the kaempferol and quercetin extract that we used was not highly purified. Therefore, the possibility of other substances affecting mitosis and hyperplasia cannot be ruled out. Nevertheless, our observations are most probably attributable to kaempferol and quercetin as a previously identified chemopreventive agent with demonstrated suppressive effects on carcinogenesis in vitro.

\section{CONCLUSION}

We have demonstrated that the administration of $P$. macrocarpa extract and its nanoparticle protects mice against colitis small intestine in mice. The protective effects were observed as suppression of mitosis and hyperplasia in crypt epithelial cells.

\section{ACKNOWLEDGMENTS}

We wish to thank the Directorate of Research and Community Service of the University of Indonesia for the PITTA research grant.

\section{CONFLICT OF INTEREST}

The authors declare no conflict of interest.

\section{REFERENCES}

1. IACR. Tumours of the Small Intestine. $1^{\text {st }}$ ed. IARC; 2016. Available from: https://www.iarc.fr/en/publications/pdfs-online/pat-gen/bb2/bb2chap4.pdf. [Last cited on 2017 Feb 22].

2. Makmun D, Simadibrata M, Abdullah M, Syam A, Fauzi A, Renaldi K, et al. Changing trends in gastrointestinal malignancy in Indonesia: The Jakarta experience. J Cancer Res Ther 2014;2:160-8.

3. Doyon L, Greenstein A. Cancer of the small bowel. In: NiederhurberJE, Armitage JO, Kastan MB, Tepper JE, editors. Abeloff's Clinical
Oncology. $5^{\text {th }}$ ed. Philladelphia, PA: Elsevier; 2014. p. 1271-7.

4. De Padua LS, Bunyapraphatsara N, Lemmens RH. Plant Resources of South East Asia. Medical and Poisonous Plants. Printed in Bogor. Indonesia (PROSEA). Leiden, The Netherlands: Backhuys Publishers; 1999.

5. Soeksmanto A, Hapsari Y, Simanjuntak P. Antioxidant content of parts of Mahkota dewa, Phaleria macrocarpa [Scheff] boerl.(Thymelaceae). Biodeversita 2007;8:92-5.

6. Hendra R, Ahmad S, Sukari A, Shukor Y, Oskoueian E. Flavonoid analyses and antimicrobial activity of various parts of Phaleria macrocarpa (scheff.) boerl fruit. Int J Mol Sci 2011;12:3422-31.

7. Suprapti T, Louisa M, Tedjo A, Fadilah K, Handjari DR, Yulhasri Y. Antiinflammatory Effect of mahkota dewa (Phaleria macrocarpa (scheff.) boerl.) leaves extract on colon carcinogenesis induced by azoxymethane and dextran sodium sulphate: Focus on the iNOS, $\beta$-catenin and COX-2. expressions. Asian J Appl Sci 2014;2:511-27.

8. Nijveldt RJ, Nood E, van Hoom EC, Boelens PG, Norren K, Leeuwen PA. Flavonoids: A review of probable mechanism of action and potential application. Am J Clin Nutr 2001;74:418-25.

9. Kadioglu O, Nass J, Saeed ME, Efferth T. Kaempferol is an Antiinflammatory compound with activity towards NF- $\mathrm{BB}$ pathway proteins. Anticancer Res 2015;35:2645-50.

10. Terada T. Malignant tumors of the small intestine: A histopathologic study of 41 cases among 1,312 consecutive pecimens of small intestine. Int J Clin Exp Pathol 2012;5:203

11. Lu H. Inflammation, a key event in cancer development. Mol Cancer Res 2006;4:221-33.

12. Erben U, Loddenkemper C, Doerpel K, Spieckermann S, Haller D, Heimesaat $\mathrm{M}$, et al. A guide to histomorphological evaluation of intestinal inflammation in mouse models. Int $\mathrm{J}$ Clin Exp Pathol 2014; 7:4557-76.

13. Lawrence $T$. The nuclear factor NF-kB pathway in inflammation. Cold Spring Harb Perspect Biol 2009; 1:a001651-1.

14. Neugut A, Marvin M, Chabot J. Adenocarcinoma of the small bowel. In: Holzheimer R, Mannick J, editors. Surgical Treatment: EvidenceBased and Problem-Oriented. $1^{\text {st }}$ ed. Munich: Zuckschwerdt; 2001.

15. Paulus U, Loeffler M, Zeidler J, Owen G, Pottern C. The differentiation and lineage development of goblet cells in the murine small intestinal crypt: Experimental and modelling studies. J Cell Sci 1993;1:473-84.

16. Dextran Sulfate Sodium Salt (36,000-50,000 M.Wt.) MP GradeCAS-9011-18-1 (02160110)-MP Biomedicals; 2016. Available from: http://www.mpbio.com/product.php?pid=02160110\&country $=100$. [Last cited on 2017 Jan 30].

17. Tanaka T, Kohno H, Suzuki R, Hata K, Sugie S, Niho N, et al. Dextran sodium sulfate strongly promotes colorectal carcinogenesis in ApcMin/+mice: Inflammatory stimuli by dextran sodium sulfate results in development of multiple colonic neoplasms. Int $\mathrm{J}$ Cancer 2005;118:25-34.

18. Suzuki R, Kohno H, Sugie S, Tanaka T. Dose-dependent promoting effect of dextran sodium sulfate on mouse colon carcinogenesis initiated with azoxymethane. Histol Histopathol 2005;20:483-92.

19. Suzuki R, Miyamoto S, Yasui Y, Sugie S, Tanaka T. Global gene expression analysis of the mouse colonic mucosa treated with azoxymethane and dextran sodium sulfate. BMC Cancer 2007;7:84.

20. Thaker AI, Shaker A, Rao MS, Ciorba MA. Modeling colitis-associated cancer with azoxymethane (AOM) and dextran sulfate sodium (DSS). J Vis Exp 2012;67:pii: 4100.

21. Perse M, Cerar A. Dextran sodium sulphate colitis mouse model: Traps and tricks. J Biomed Biotech 2012;2012:1-13.

22. Nanoparticle Technology. Available from: http://www.gitam.edu. [Last cited on 2016 Sep 05].

23. Singh R, Illard JW. Nanoparticle-based targeted drug delivery. Exp Mol Pathol 2009;86:215-23.

24. Tjandrainata RR, Djunarko I, Fenty F, Hendra P. Anti-inflammation effects of bioactive fraction DLBS0533 containing Phaleria macrocarpa and Nigella sativa on animal model. Int J Pharm Pharm Sci 2015;7:408-11.

25. Tjandrawinata RR, Rouli HC. A role for Phaleria macrocarpa (Scheff) Boerl. extracts in the management of women's pathological conditions: A research review. Int J Pharm Pharm Sci 2017;9:7-12. 